\title{
UNIQUE FEATURES OF JAPANESE RYODORAKU THERAPY
}

\author{
Masako Ono, M.D. Ph. D.
}

\section{What is Ryodoraku?}

The Japanese word Ryodoraku is a compound of three Chinese characters. Ryo means good, do means electroconductive and raku means linked lines or meridians. There exist on the skin of the human body some points of unusually high electric conductivity called ryodoten. Hereafter I will refer to the term "ryodoten" as the ryodo-point. There are two types, the ryodo-points (21V. D.C. $200 \mu \mathrm{A}$ ), which are

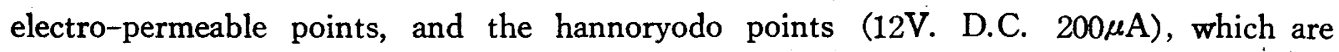
reactive electro permeable points (R.E.P.P.). I shall explain these later.

I would like to provide some background information on this topic. Sometime around 1950, the late Dr. Yoshio NAKATANI discovered the above phenomenon. At that time, Professor SASAGAWA, physiologist of Kyoto University, called the lines connecting these points Ryodoraku. From these discoveries, Ryodoraku research originated. Ryodoraku 'Therapy is closely related to the autonomic nervous systme. This provides the scientific basis for the therapy. I shall briefly outline the principal points.

Fig. 1

\section{RYŌDŌRAKU TERMINOLOGY}

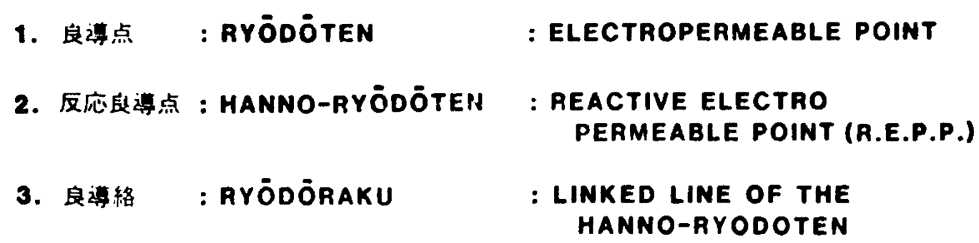

\section{What are the Ryodo-points?}

Ryodo-point means a 'good electro-permeable point' on the surface of the skin. An active cathode of less than $1 \mathrm{~cm}$ in diameter may be used to measure the electric resistance of the skin. If 21 Volts Direct Current is applied while the indifferent anode is held in one hand, a number of spots showing higher electroconductivity than the surrounding skin area may be observed over almost the entire body surface. These spots are called Ryodo-points.

When 12 Volts D.C. is used instead, far fewer spots appear. They are characteristic of unhealthy states of the body and are called Reactive Ryodo-points or Reactive Electro-permeable Points-R.E.P.P. Reactive Ryodo-points are caused by the reaction of malaised part of the body through the patho-physiological autonomic nerve reflexes. 
Fig. 2

\section{WHAT ARE R.E.P.P. ?}

\section{Reactive Electro-permeable Points.}

\section{R.E.P.P. are Ryōdō-points caused by the reaction of malaised parts of the body through the}

patho-physiological autonomic nerve reflexes.

We have attempted to show R.E.P.P. in photography just as it is defined according to the density of the local electric flow in clinical use. Local electric current became visible by means of an electrochemical reaction, as shown in Fig. 3. The complex chemical compound of silver and iodine appears at the end of the reaction. This chemical compound produces the brown-black color change, in proportion to the proton-flow from the anode where 12 volts D.C. of 1 or $2 \mathrm{~mA}$ is applied from 5 to 20 minutes. It can be accumulated on a silver-plated mirrored surface of $4 \mathrm{~cm}$ diameter attached to the skin as the anode. Thus, distribution and shape of Ryodo-points have been successfully photographed.

At the stomach Meridian 36, according to mann's nombering a horsesoe-like spot of $2 \mathrm{~mm}$ appeared by this method. Scales at the bottom shows $1 \mathrm{~mm}$. Fig. 6 shows one reactive Ryodo-point, such as at the spleen meridian six, san-ying-chiao, consisting of several small irregular shaped spots of $1-2 \mathrm{~mm}$. They apparently gather to form one REPP of fingertip size, which is usually considered tobe the size of an acupuncture point.

R.E.P.P. are influenced by the pathological excitation of the sympathetic innervation of the local skin, and are also related to the function of the whole autonomic nervous system. When appropriate stimulation is administered to such points, reflexes are induced between these sensitive points and connected organs or tissues of the body. These reflexes adjust the malfunction of the nervous system and its innervated organs. This self-balancing mechanism is usually referred to as the homocostasic mechanism of the human body. This is one of the main concepts of Ryodoraku. We can call this application technique focused autonomic regulating therapy.

\section{Measurement of the Electrice Resistance of the Skin}

When the electric resistance of the skin is measured, three components are involved. They are the sweat glands, the hair follicles, including sebaceous glands, and the cutis itself. Sweating generally decreases the resistance of the skin, but its influence should correspond to the sweating area and cannot be so localized as ryodo-points. Insensitive perspiration always exists in the duct of the sweat gland, although sweating may not obviously appear on the skin surface.

These sweat glands can be seen in Fig. 9 by the same silver and iodide reaction technique, but they are apparently different from R.E.P.P. 
This Fig.10 is a cirkit of the equipment used in both Ryodoraku Therapy and measurment. We usually use 12 volts and $200 \mu \mathrm{A}$.

In order to eliminate the state of sweating on R.E.P.P. measure-ments, a wet electrode with a physiological saline-soaked or $30 \%$ alcohol cotton ball fitted into an ebonite cap is recomended as an active electrode that is cathode. However, a dry electrode with a metal tip is still more practical in locating ryodo-points.

The active state of the stratum corneum and corium associated with the function of the sebaceous glands may be the main factor to cause such localized spots of lower electric resistance than the surrounding area. They are considered to be produced by an excited state of the local sympathetic nerve innervation.

There are several other factors which affect electroconducti-vity of the skin which must be taken into consideration, such as existence of injury, edema, or dirt.

Special attention must be given to the fact that skin electroresistance is unstable and easily affected. In addition, false Ryodo-points can be created by the use of electric current, repeated applications of an active electrode, machanical stimulation, etc. Therefore, measurements must be done within a few seconds of the electrode application on the intact skin surface.

\section{Physiological basis Ryodoraku Therapy}

\section{(a) General Regulation of the Autonomic Nervous System}

Stimulation applied to any part of the surface of the human body triggers reactions thronghout the body via the routes of the afferent and efferent nerves connected to each other through the Central Nervous System. (C.N.S.) Thus, reflexes of the sympathetic and parasympathetic nerves are induced to maintain or restore the balance between them by means of the homeostatic mechanism of the body.

This mechanism can regulate all organs of the body, such as the cardiovascular system, the gastrointestinal tract, and functions of the exocrine and endocrine glands. It is generally understood that stimulation applied to the hypothalamic pituitary system triggered by peripheral nerve stimulation has several effects. It increases the insulin secretion of the pancreas, improves the neurohumeral function of both the suprarenal and the thyroid glands, and produces some leukocytosis. These effects may be induced by the proper amount of stimulation applied to the appropriate skin site by means of electroacupuncture.

Cutaneous stimulation by needling the Head's zone is transmitted to the spinal cord and then ta the segmentally related organs such as the liver (as shown in this Fig.12), the pancreas, or the gall-bladder to trigger the restoration of their functional balances, and also to other organs via the deep somatic and autonomic nervous system. Thus, Ryodoraku may be understood to work as a form of non-specific stimulation therapy through the entire autonomic nervous system.

\section{(b) Local effects}

Acupuncture also has local effects. These appear within half an hour as an unspecific reaction of the local tissue. This is seen in histology as vasodilatation of arteriolae, venuelae, and small lymph vessels, as well as granulocyte infiltration, and hyperamia in the cutis and subcutaneous tissue. You can see the needle insertion hohle as this white 
line.

Also Ryodoraku results in the improvement of local circulation and the relaxation of the underlying muscles. After 10 seconds of applying 12 Volts D.C., minor damages occur such as swelling, waxy degeneration and granular disintegration of the muscle fibers surrounding the path way of the needle insertion (as shown in Fig.14) You can see the acupuncture needle penetration hole through the muscle tissue. Fig.15 with higher magnification, shows similar swelling, waxy degeneration, and granular disntegration of the muscle fiber. Also, edema can be seen in the interstitial tissue.

In summarizing histological changes due to acupuncture, these are seen grade by grade. However, the size of the locus minoris resistantie is so small and the local reaction of leukocytosis and vascular dilatation around the needle insertion is strong enough to counteract the bacterial infection as a defence mechanism. Nevertheless, we strongly recommend the sterilization of needles against possible virus infection.

\section{How is Ryodoraku Therapy Practiced?}

There are 3 main methods. They are general, focused regulating therapy, and local electric acupuncture. Ryodoraku may be represented as a total of 26 linked lines (or meridians) connecting the R.E.P.P. That is, Ryodoraku is likely to appear most along the classical meridians in most cases, but some R.E.P.P. appear not to correspond to any meridians.

Thus, R.E.P.P. function both as a system for understanding abnormal conditions and as a system of therapy. The electric flow volume is measured at a representative measuring point on each Ryodoraku.

Fig.17 shows representative measuring points. The measured values are marked in corresponding columns of a specially designed Ryodoraku nomograph, invented by Dr. NAKATANI. When the measured values on the graph appear approximately in a horizontal line, the subject is considered to be in good health. The slide shows a patient one month after treatment for a frozen shoulder.

However, if a wide discrepancy of high and low values appears outside the physiological range, symptomatic unbalance is present. From experience, the physiological range between high and low may vary around $1.4 \mathrm{~cm}$ in normal healthy subjects. When the range exceeds this, it may be taken as evidence of an imbalance in the body. This may be treated at recommended points. This patient is the samc patient as in Fig.18, before the treatment.

The recommended points, when stimulated, induce a balance within the body and therefore are valuable in treating chronic conditions. Dr. NAKATANI recommended these points, as in Fig.20 and Fig.21, from his experience with many patients. However, selection of high points for increasing or low points for lowering the conductivity level is not absolutely necessary, because of the homeostatic mechanism, as already explained. Future research may lead to the modification of the nomograph. However, it is a useful working basis for treatment which has proved its clinical value.

General Basic Points :

These general basic points are usually recommended to be used in combination with general regulating therapy. 
Head and Neck Points :

These points should also be used to reinforce the effect of local and general treatments in most chronic diseases.

This Fig.22 is a picture of adjusting a neurometer. The meter is calibrated in micron amperes. You can see the three dials below the meter. The middle one regulates the voltage (6, 12, 21 volt), while the one on the right adjusts the current. Below the dial you can see the grip electrode and the detecting electrodes.

The most effective R.E.P.P. is found by reading the dial of the neurometer. As the patient holds the positive electrode in one hand, the negative electrode is used to detect the R.E.P.P. The voltage is $12 \mathrm{~V}$ (D.C.), and the amperage is previously set with a regulator so that the full scale $200 \mu \mathrm{A}$ is read when the wet detect electrode and grip electrode are in direct contact.

Linked lines of reactive Ryodo-points are called Ryodoraku, meaning 'high electroconductive meridians'. All acupuncture points and meridians do not always show high electroconductive states. R.E.P.P. are the patho-physiological manifestation of the subject. This slide shows linked lines of R.E.P.P., which roughly coincide with the traditional kidney meridians. This was the first discovery made by Dr. NAKATANI while searching for electroconductive points on nephritis patients, and this finding led to the development of Ryodoraku theory and practice.

We have developed a modernized method of automatically measuring the skin resistance, spot by spot, by the use of an on-line computer system. A series of wet electrodes of $1 \mathrm{~cm}^{2}$ were attached on the skin equally and switched on one after another to measure the amperage by an Auto-neuro Calculator. Sequential readings every 0.5 seconds were fed into the computer. The computer then calculated the ratio of difference of conductivity at $\mathrm{B}$ against both sides of spots ( $\mathrm{A}$ and $\mathrm{C}$ ) by the formula as shown in this slide. Values have been taken for different body areas, e.g. back, forearms, shoulders and legs. If the difference is greater than $50 \%$, then it is a ryodo-point.

Fig.27 shows many Ryodo-points, found by an on-line computer system on the inner side of the right leg of a patient suffering from chronic renal insufficiency. Since no subjective factors enter the measurement process, the result may be considered objective. These spots, which are over $50 \%$ higher than those on either side, coincide

Fig. 26

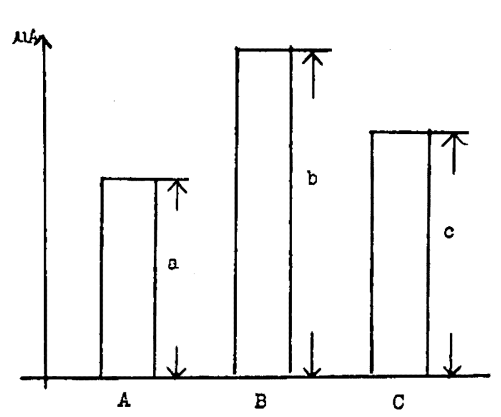

$$
\begin{aligned}
& \frac{b-a}{b} \times 100=P_{a} \\
& \frac{b-c}{b} \times 100=P_{c} \\
& \text { A of both sides eloctrodcs are } \\
& \text { compared by abcre calculaticns. } \\
& M=P_{a} P_{c} \\
& M(\&): \text { CATEGonY of a Ryodo-Foint } \\
& \text { ie, orer } 50 \text { \& } \\
& \text { Then, B is a Ryodo-Foint }
\end{aligned}
$$




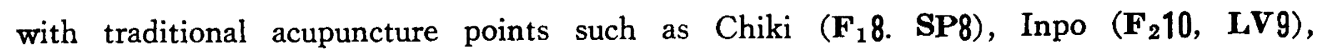

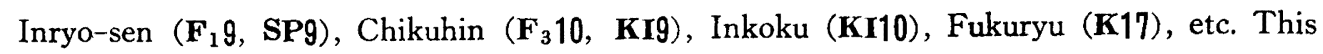
percentage was found from the calculations of the previous formula, which was used to compare the electroconductivity and it $s$ adjacent areas. According to traditional meridians, these R.E.P.P. linked lines roughly coincide with $F_{1}$ (the spleen meridian), $\mathrm{F}_{2}$ (the liver meridian), $\mathrm{F}_{3}$ (the kidney meridian), etc.

\section{Survey of Present Status of Ryodoraku Practice in Japan}

Currently, there are 935 physicians and 300 acupuncturists who belong to the Ryodoraku Autonomic Nervous System Association in Japan. However, the number of Japanese doctors practicing Ryodoraku treatment is over 40,000. A questionnaire was sent to members of the Association for the purpose of compiling data on Ryodoraku treatment in Japan. The contents of the questionnaire included such items as determining the diseases which are most effectively treated by Ryodoraku, the side effects and complications caused by Ryodoraku treatment, and the period necessary for effective treatment to become effective.

The following is a list of painful diseases and syndromes which responded well to Ryodoraku treatment. Only those diseases which were listed by at least 5 different doctors are shown here, in descending order. Low back pain, neuralgias, and a stiff neck and shoulder area were most effectively relieved by Ryodoraku treatment.
1. Low back pain
2. Neuralgias
3. Stiff neck and shoulder
4. Scalpohumeral Periarthritis
5. Other painful disorders
6. Headache
7. Sciatica
8. Rheumatoid Arthritis
9. Migraine
10. Herpes Zoster
11. Knee pain
12. Toothache
13. Tonsilllar pain
14. Muscle pain

15. Stomachache

Here is the magnification of the tip of an acupuncture needle which has not been used, compared with that of a needle used on one patient. The surface of the needle has become worn. Near the center of the needle you will find scratches resulting from friction between the needle and the skin. (Figure omitted.)

Here the new needle is also compared with one used for treating sever patients with numerous Pecking insertions. The point of the needle has become blunt, not due to the direct result of electricity, but mainly due to mechanical wear caused by piercing the tissues. (Figure omitted.)

The following is a list of various: diseases and symptoms clearly showed a positive response to Ryodoraku treatment. The neckshoulder-arm syndrome had the highest response, followed by in descending order, Bronchial Asthma and Autonomic Nervous Disturbances.
1. Neck-Shoulder-Arm-Syndrome
2. Bronchial Asthma
3. Autonomic Nerve Disturbances
4. Sprains
5. Facial Palsy
6. Hypertension
7. Dyschromatopsia
8. Osteoarthritis 
9. Climateric Disorders

11. Menieres Disease

13. Anthropathy

15. Enuresis Nocturna

17. Asthenopia
10. Hemorrhoids

12. Meniere's Symptom Complex

14. Neurosis

16. Insomnia

The following is a list of the number of side-effects or complications resulting from Ryodoraku acupuncture treatment. Common side-effects such as acute cerebral ischemia, fatigue, localized pain and shock are only transitional.

Side-Effects (total 238 reports)

1. Acute cerebral anemia

2. General fatigue

3. Local pain

4. Shock

5. Exacerbation

6. Sugillation, hematoma

7. Pneumothorax

8. Broken needles

9. Sleepiness

10. Fever

11. Dizziness

12. Nausea, Vomiting etc.

Here we can see two of the serious complications. However, they were actually caused by careless mistakes. Therefore, we must always take extreme care when treating patients.

\section{Serious Side-Effects}

Pneumathorax 16 cases (10 reports) 6\% (4\%)

Broken needles 10 cases ( 8 reports) $4 \%$ (3\%)

The next item is the period necessary for treatment to become effective. This chart indicates thes cures resulting from Ryodoraku treatment. The cure can be accomplished in one day in many acute cases.

TABLE 1. Period to become effective

\begin{tabular}{ll}
$<1$ day & $63(25 \%)$ \\
$1-2$ day & $45(18 \%)$ \\
$3-6$ day & $40(16 \%)$ \\
$>7$ day & $41(16 \%)$ \\
Unclear & $62(25 \%)$ \\
\hline Total & $251(100 \%)$
\end{tabular}

This Table 2 is summary of patients treated only with Ryodoraku therapy for chronic pain by Dr. NAKATANI in 1972. The results of all cases in this table were confirmed by a follow-up study, and cure and improvement were seen in total 76 out of 79 cases, or a $96 \%$ sucess rate.

TABLE 2 Acupuncture treatment for chronic pain syndrome

\begin{tabular}{|c|c|c|c|c|c|c|c|c|c|}
\hline \multirow[b]{2}{*}{ Maladies } & \multirow{2}{*}{$\begin{array}{c}\text { No. } \\
\text { of } \\
\text { Cases }\end{array}$} & \multicolumn{5}{|c|}{ Number of times of treatment } & \multicolumn{3}{|c|}{ Results } \\
\hline & & $1-5$ & $6-10$ & $11-20$ & $21-30$ & $31-$ & Success & Improvec & No change \\
\hline Lumbago & 30 & 20 & 4 & 4 & 0 & 2 & 17 & 12 & 1 \\
\hline Sciatica & 10 & 6 & 3 & 1 & - & - & 2 & 7 & 1 \\
\hline Whiplash injury & 6 & 2 & 1 & 0 & 2 & 1 & 2 & 4 & - \\
\hline
\end{tabular}


Facial neuralgia

\begin{tabular}{|c|c|c|c|c|c|c|c|c|c|}
\hline $\begin{array}{l}\left(\begin{array}{l}\text { trigeminal } \\
\text { occipital, etc. }\end{array}\right) \\
\text { Shoulder-hand }\end{array}$ & 6 & 0 & 2 & 3 & 1 & - & 3 & 3 & - \\
\hline \multicolumn{10}{|l|}{ Syndrome } \\
\hline (frozen shoulder, etc.) & 21 & 13 & 4 & 2 & 1 & 1 & 3 & 17 & 1 \\
\hline Headache & 6 & 3 & 1 & 2 & - & - & 2 & 4 & - \\
\hline & 79 & 44 & 15 & 12 & 4 & 4 & 29 & 47 & 3 \\
\hline
\end{tabular}

\section{Summary of Ryodoraku Therapy}

This table summarizes the main points of Ryodoraku treatment. This technique is understood very simply as a type of non-specific stimulation therapy which regulates the balance of the autonomic nervous system on the basis of the homeostatic mechanism. Secondly, it may be used easily in clinical practice by physicians who have had training only in conventional medicine. Thirdly, since objective scales are obtained by use of electricity, treatment points may be easily found, Fourthly, it is a safe and dependable method of acupuncture for treating various painful disorders as well as other functional for imbalances in the body. Finally Ryodoraku therapy is a step towards understanding the scientific basis of acupuncture, which may help to convince skeptical physicians that it is effective.

\section{CONCLUSION (RYODORAKU TREATMENT)}

(1) Understood slmply as regulating the balance of the autonomic nervous system.

(2) Easy in clinical practice.

(3) Treatment points easily found by neurometer.

(4) Safe and dependable.

\section{Bibliography}

Dr. Masayoshi Hyodo,

Ryodoraku Treatment: An Objective Approach to Acupuncture. (Ryodoraku Autonomic Nerve Society,1975)

Dr. Yoshio Nakatani and Dr. Kumio Yamashita, : Ryodoraku Acupuncture(Ryodoraku Research Institute, 1977)

Dr. Toru Sato and Dr. Yoshio Nakatani "Acupuncture for Chronic Pain in Japan" Advances in Neurology, Raven Press New York, 1974. pp813-818

Untranslated Japanese sources not listed.

Slides on histology and needle points by courtesy of Professor Toru Sato of Tottori University Department of Anesthesiology, Yonago City, Tottori-ken.

Appearance of Ryodo-Points by the electrochemical reaction and computerized measurement of Ryodo-Points are from works in progresss by a group under Professor Toru Sato at Tottori University.

Survey of Ryodoraku treatment in Japan comes from research by Dr. M. Ono and Dr. N. Yamauchi Published in The Japanese Journal of Ryodoraku No. 9., Sept. 1981, Vol. 26. pp 219 224. 
Fig. 3

$$
\begin{aligned}
\mathrm{Ag}_{2} \mathrm{O}+2 \mathrm{KI}+\mathrm{H}_{2} \mathrm{O} & \longrightarrow 2 \mathrm{AgI}+2 \mathrm{KOH} \\
2 \mathrm{I}^{-} & \longrightarrow \mathrm{I}_{2}+2 \mathrm{e}^{-} \\
(\mathrm{KI} & \left.\longrightarrow \mathrm{K}^{+}+\mathrm{I}^{-}\right) \\
\mathrm{n} \mathrm{AgI}+\mathrm{mI}_{2} & \longrightarrow \text { nAgI.m }_{2} \mathrm{ml}_{2}
\end{aligned}
$$

Fig. 4

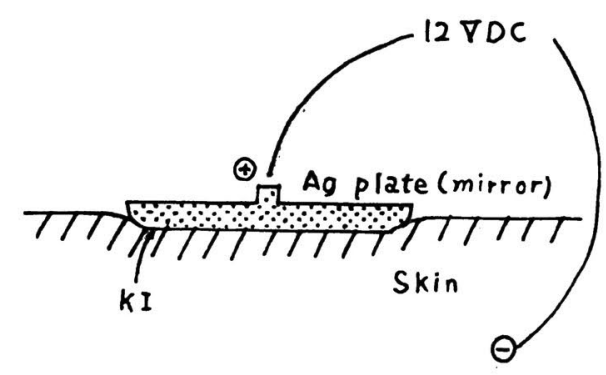

Fig. 5

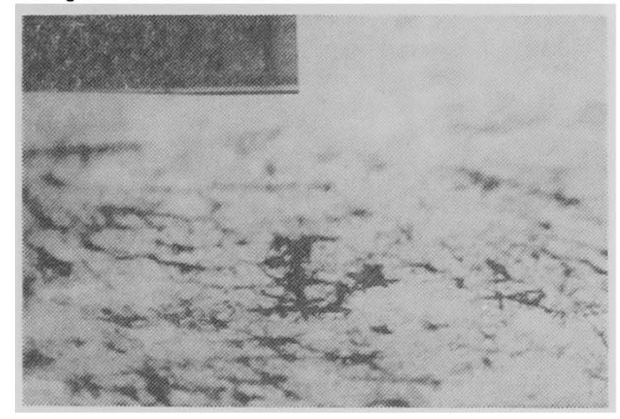

Fig. 6

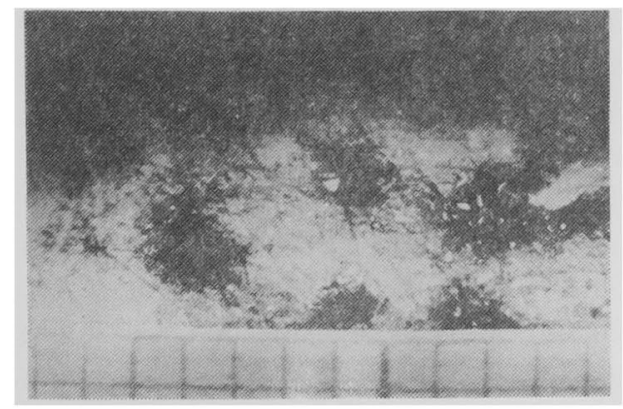

Fig. 7

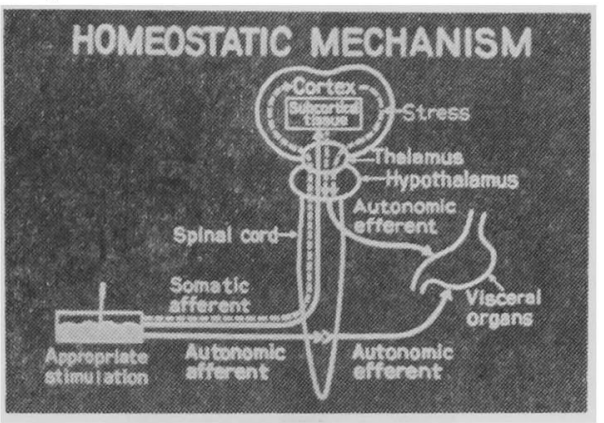

Fig. 8

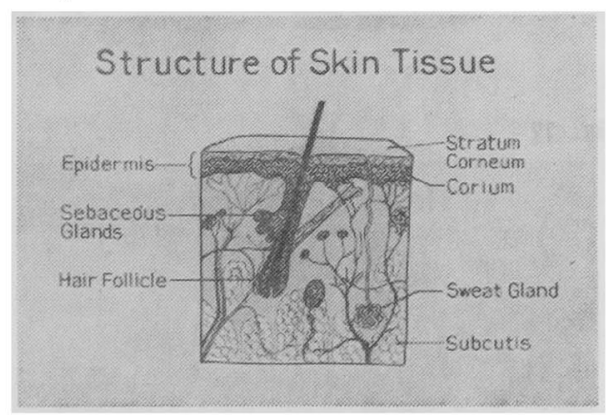

Fig. 9

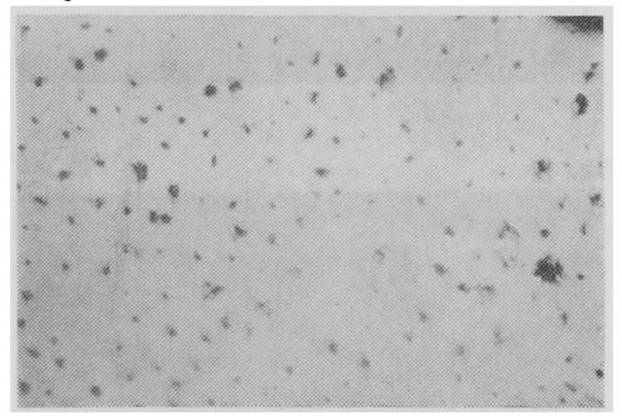

Fig. 10

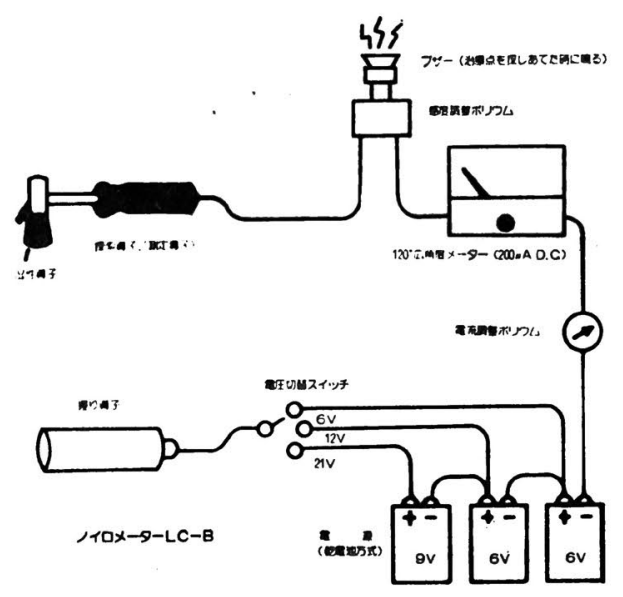


Fig. 11

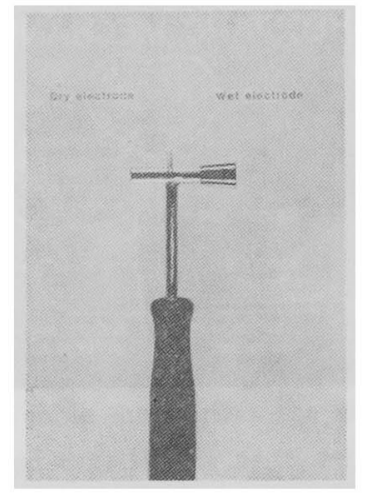

Fig. 12

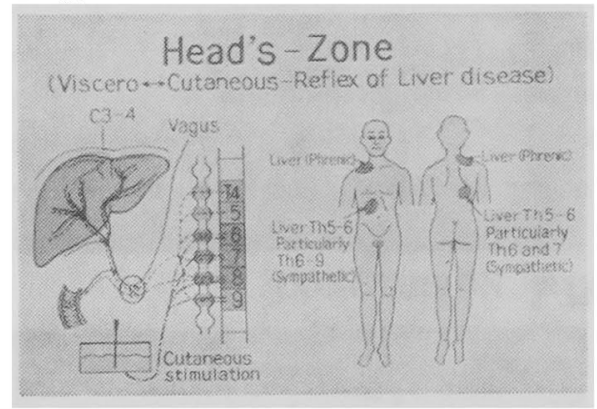

Fig. 13

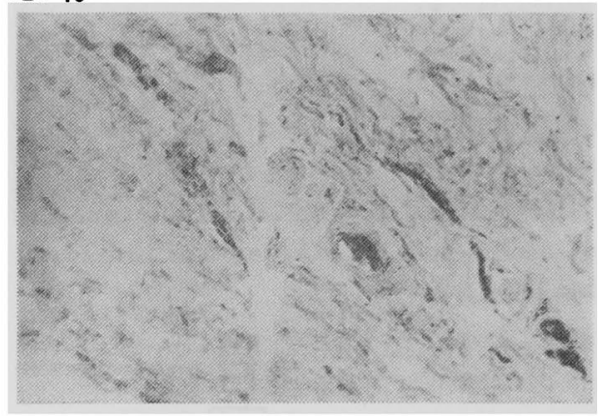

Fig. 14

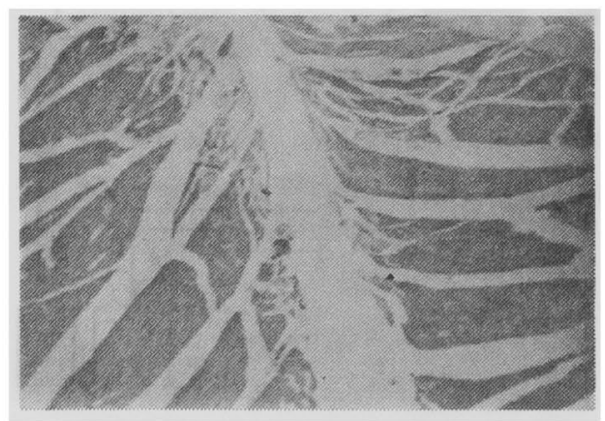

Fig. 15

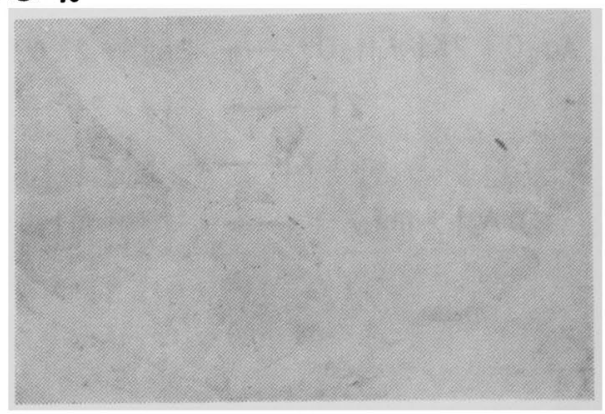

Fig. 16

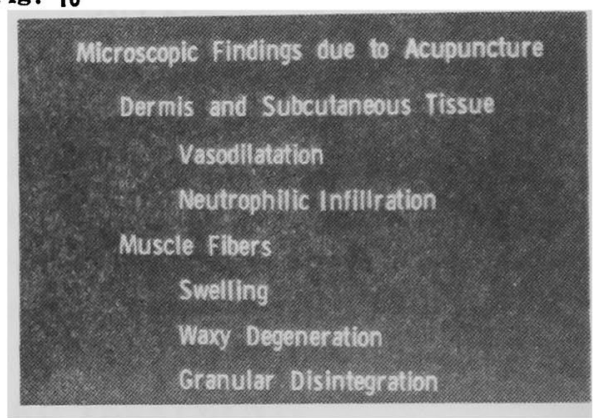

Fig. 17

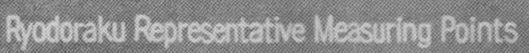

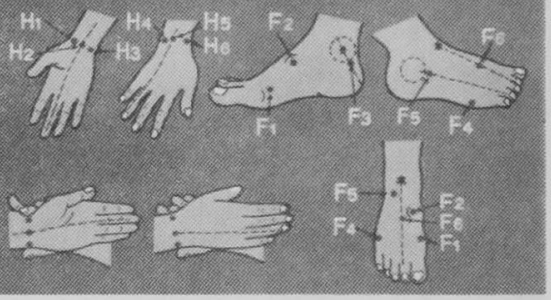

Fig. 18

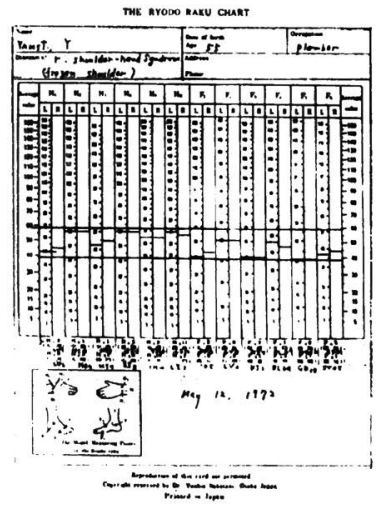


Fig. 19

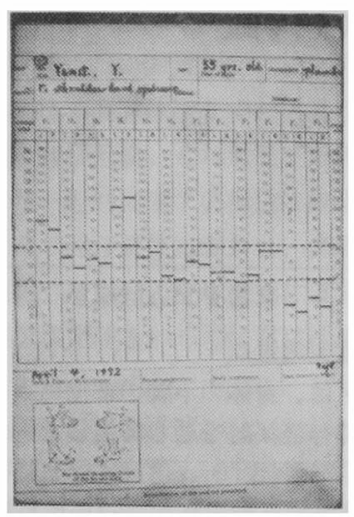

Fig. 20

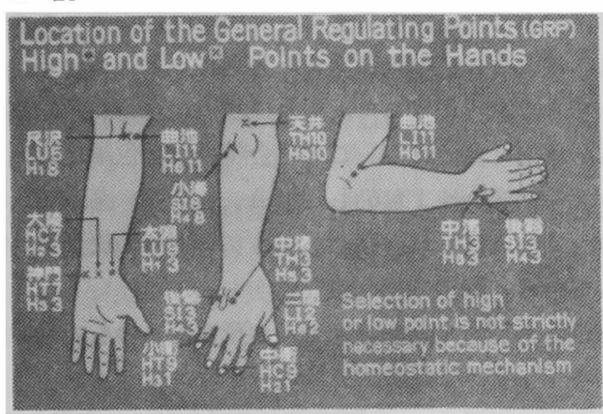

Fig. 21

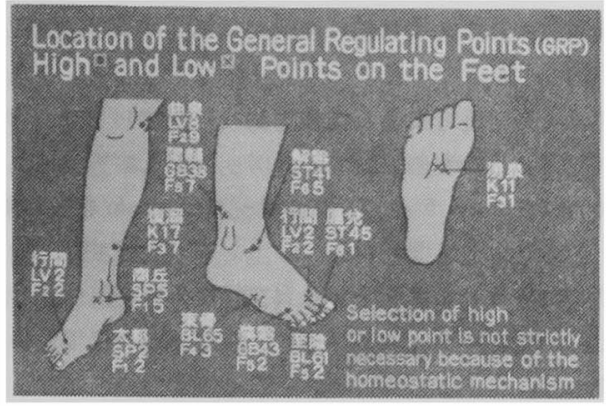

Fig. 22

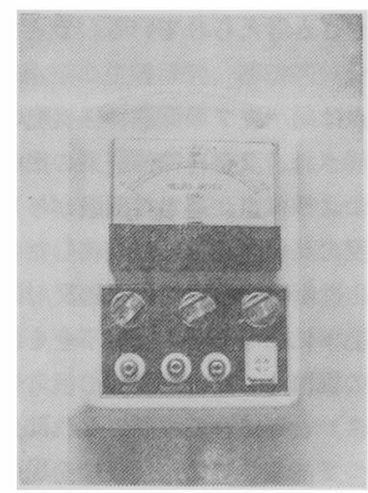

Fig. 23

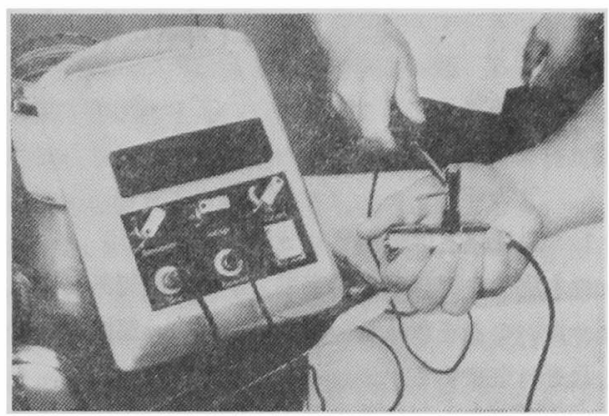

Fig. 24

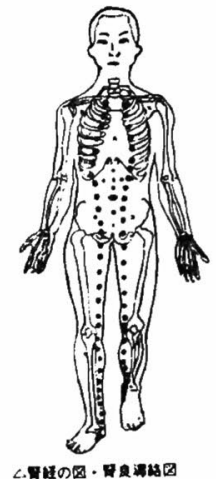

Fig. 25

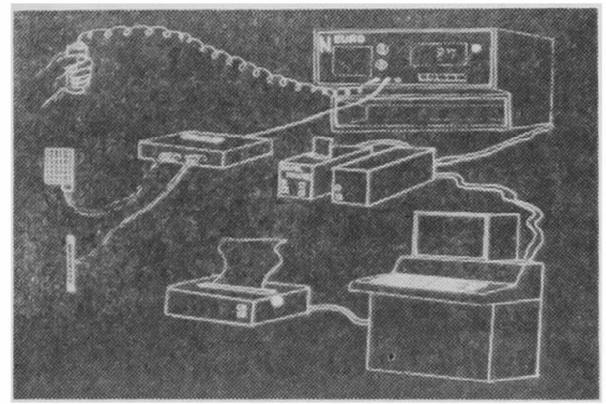

Fig. 27

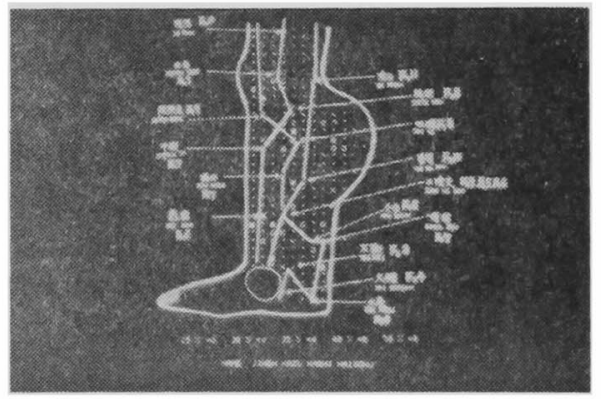




\section{日本における良導絡治療の特徵}

小野昌子

\section{1. 良導絡亡は何か?}

日本語の良導絡とは漢字三文字の合成であって、良 は、良いととを意味し、導は電導性を、絡は連結線を それぞれ意味する。

人体の皮清上には良導点と呼ばれる、通常電導性の 高い点がいくか存在する。以後、“良導点、という 言葉を良導ポイントと呼ぶことにする。これには二つ のタイプがあり、一つは電気がよく通りやすい点であ る $(21 \mathrm{~V} 200 \mu \mathrm{A}$ D.C) 良導ポイントであり、もう一 つは反応良導点（12V200 $\mu$ A D.C.RE P P である。 これらのあのについてあとで説明する。

この話題については、背景となるいくつかの情報を 提供したい。1950年頃、故中谷義雄博士が前述の現象 を発見され、当時、京都大学精神科の笹川教授が、乙 れらの点を結ふ線を良導絡と名付けられた。この発見 から良導絡の研究が始まった。良導絡治療は、自律神 経系に密接関系している。このととは本治療に科学 的根拠を提供するあのである。主要点について、簡単 に概要を述へたい。

Fig. 1

\section{良導絡の用語}

1. 良 導 点: 電気のよく通る点

2. 反応良導点： 12 Volt でもなお解明に良導点 が現われる点

3. 良導絡：反応良導点の連結線

\section{2. 良導点とは何か}

良導点とは皮つの表面における電気のよく通る点之 いうととを意味する。皮フの電気抵抗を測定するに は、直径 $1 \mathrm{~cm}$ 末満の活性陰極が用いられる。一方の 手に不関性陽極を持ち 21 Volt の直流を流すと、まわ りの皮フより高電導性を示す多数のスポットが（との スライドに見られるように）殆んど全身の表面に観察 される。これらのスポットを良導ポイントと呼ふ。 21 Volt でなく12Volt を流すと、スポットははるかに少 なくなる。これらのスポットは健康体でない状態では 特徽的であり、反応良導点又はR E P P と呼ばれる。 反応良導点は身体の不調の部位の反応により、病理生 理学的な自律神経反射を通して生じたものである。
Fig. 2

\begin{tabular}{|c|}
\hline R E P P とは何か \\
反応性電気透過点 \\
RE P P は、身体の不調の部位により、病理生 \\
理学的自律神経反射を通して生したものである。
\end{tabular}

我々は、良導絡定義にあとついたREP P（反応良 導点）が局所電流密度によって表われるのをそのまま 写真で示そうと試みてきた。局所電流はてのスライド にあるように、電気化学反応方法により眼で見るてと ができるようになった。銀及び沃度の複合化合物が反 応の終末に表われる。この化合物は黒褐色に变じる が、その度合は 1 ないし $2 \mathrm{~mA} 、 12$ Volt 直流を 5 な いし20分荷電した陽極から出るプロトンの流量に比例 している。

Fig. 3（図版は前出（9 頁以下）のあのを参照 ください。)

方法、直径 $4 \mathrm{~cm}$ の銀鏡板の表面を皮つに密着して、 それに陽極につなき、蓄皘してくる。このようにして 良導点の分布と形を写真に撮るのに成功した。

Fig. 4

マン経絡番号による胃経絡36 (足三里) において （直径） $2 \mathrm{~mm}$ の馬蹄型のスポットがての方法により 表われた。(スライド下のスケールは $1 \mathrm{~mm}$ を表わす)

Fig. 5

てのスライドは脾葴経 6（三陰交）の所に表われ た反応良導点の一つを示しており、これは 1 ないし $2 \mathrm{~mm}$ のさい不規則な形をしたいくつかのスポット でできている。てれらは明らかに、集合して指先ほど の大きさのREPP（反応良導点）を形成し、通常 刺激点の大きさと考えられている。

Fig. 6

反応良尊点は局所皮フの交感神経支配の病理学的興 奞により影響され、又全自律神経系の機能にす関連し ている。とのような点に適当な刺激が与えられると、 てれらの感度の高い点とそれに連絡した身体の器官又 は組織の間に反射が起る。これらの反射は、神経系と その神経支配下にある器官の機能不全を調整する。乙 の自己平衡の機構は、通常、人体の恒常性機構（ホメ オスターシス) と呼ばれており、とれは良導絡の主要 な概念の一つである。この応用技術を局所自律神経調 
節治療と呼ふととができる。

Fig. ๆ ホメオスターシス機構

\section{3. 皮フの氛気抵抗の測定}

皮フの電気抵抗の測定には三つの要素がある。即ち 汗腺、皮脂腺を含む毛意、それに皮フそのあのであ る。発汗により一般的に皮フの抵抗は減少する。しか しその影稫はその発汗部位に表われ、良導点のように それほど局在化してない。皮フ表面には明瞭に表われ なくても不感蒸泄発汗というのは常に汗腺の管の中で 起っている。

Fig. 8 皮フの構造

てれらの汗腺は(この Fig. 9 で)前述した方法と同 じ方法の銀及び沃度の反応方法によって見られるが、 明らかにR E P P（反応良導点）とは異なっている。

Fig. 9

良導絡治療及び測定に用いた装置の回路である。我 々は通常12Volt $200 \mu \mathrm{A}$ を使用した。

Fig. 10 回路図

R E P P 反応良導点测定において、発汗状態を除去 する為には、生理的食塩水に浸した綿球をエボナイト のキャップに詰めた湿式電極が、活性電極としてすす められる。しかし金属片の乾式電極は、良導点の位置 を見つけるにはより実用的である。

Fig. 11 湿式及び乾式電極

皮脂腺の機能に関係する角質層及び真皮の活性状態 は、周囲の皮フより電気抵抗の低いとのような局在化 スポットを生じさせる主要ファクターであるかむしれ ない。皮フの電導性に影䇺を及ほすファクターとして は、他に修害、浮腫、アカといった考虑に入れなけれ ばならないあのがいくつかある。

皮フ笔気抵抗が不安定で容易に影整をうけるという 事実に特に注意を払わなければならない。さらに、電 流の使用法、活性電極の繰返し適用、機械的刺激等に よって䛠った良尊点が作られる可能性がある。従って 測定は皮フ表面に手を触れずに敕極をあててから数秒 以内に（例えば $1 、 2 、 3$ と数をかえるように）実施 しなければならない。

\section{4. 良斑格治療の生理学的、基礎的部分}

(a) 自律神経の全身的調整

人体表面のどの部分にです与えられた刺激は、中枢 神経系（CNS）を通して互いに連結している求心性 及び遠心性の神経を経由して身体全体に反応を惹起す る。その結果、交感神経及び副交感神経の反射は、身 体のホメオスターシスによりとの両者の間の平衡を保 持又は修復する。この機構により、心臟血管系、胃腸 管、外分泌及び内分泌肺の機能といった身体の全器官 が統制される。一般に、末梢神経刺激により惹起され
視床下部下垂体系に与えられた刺激はいくつかの影鳘 を起すととがわかっている。膵蕠のインシュリン分泌 増加、副腎及び甲状腺の両神経夜の改善、ある種の白 血球増多症の産生といったあのである。これらの影響 は電気ハリによって相当する皮フ部位に与えられた刺 激の適当の量により起されるあののようである。

Head's zone 刺針による皮フ刺激は、脊髄に伝達さ れ次いで、肝灆やあるいは膵臟、胆莀といった分節的 に関係のある器官に伝達されてそれらの機能的平衡の 修復の引金となり、又さらに深部体神経及び自律神経 系を通して他の器官に伝達される。このように良導絡 とは、全自律神経系を通した韭特異的刺激型として作 用するものと理解される。

Fig. 12

(b) 局所効果

刺鍼には、局所勃果もある。とれらの勃果は局所組 織の非特異的反応として30分以内に表われる。てれは 組織学的には、細動脈、細静脈、小リンパ管の拡張、 同時に真皮及び皮下組織における顆粒体浸潤及び充血 として見られる。（刺針穴が白い線となって見える）

Fig. 13

良導絡は、また局所循環の改善及びその筋肉の弛緩 をあたらす。12 Volt D. C. 適用後10秒で、刺針の通 路をかとむ筋肉線維の腫張、万う様変性、及び顆粒崩 壊といった軽敛な損甥が起る（筋肉組織を貫通した刺 針の穴がことにみえる)

Fig. 14

Fig. 15 は高倍率に拡大したものであるが、同様に 筋肉線維の腫脹、ろう様変性、顆粒崩壊を示してい る。間質組織の浮腫も見られる。

Fig. 15

筋変性、ろう様変性、腫脹、ノイロメーター 15秒 $167 \mu \mathrm{A} \quad 10 \times 4$

ヘコトキシリン・エオシン染色

刺銊による組織学的変化を要約すると、その程度は 段階的に見られる。しかし、抵抗減少部のサイズは非 常に小さく、刺針のまわりの白血球増多及び血管㹡張 の局所反応は強力であり、細菌感染に対し防整機構と して充分作用する。それであなおウィルス感染の可能 性があるので、針の消毒を強くすすめる。

Fig. 16

刺銊による顕微鏡所見

真皮及び皮下組織

血管拡張

好中球浸潤及ひ浮腫

筋線維

腫脹 
ろう様変性

顆粒崩壊

\section{5. 良導絡治療方法について}

主に三つの方法があり、一般治療法、焦点調節治療 (focussed regulating Therapy)、局所電気鏚術(local electric Acupuncture) である。

良導絡はR E P P （反応良導点）を結ふ、全部で 26 本の連絡線によって表わすととができよう。つまり、 良導絡はほとんどの場合、従来の経線にほほ沿った形 で現われるととが多いがR E P P の中には経線のそば に現われないものもある。このように反応良導点は、 身体の異常の診断と、治療法としての働きとをあわせ 持っている。電流量は各良導絡の测定点で測定され る。これが代表的な測定点である。

Fig. 17

測定値は、中谷博士が考案した、特殊な良導絡（カ ルテ）の該当欄に記入される。测定值がグラフ上にほ は水平涀われる時は、被測定者は健康であると考え られる。Fig. 18 の患者は、五十肩の治療後 1 力月を 経過したあのである。

Fig. 18

しかし、測定値の高い值と、低い值いとの差が生理 学的範囲を越えるほど大さい時は、症状的不平衡の状 態にあることを示す。健康体の場合、測定值の生理学 的範囲は約 $1.4 \mathrm{~cm}$ の中であるととが、経験的にわか っている。ての籁囲を越える時は、身体の不平衡のあ らわれではないかと考えられる。その治療は指示され た点で行う。この患者は前のFig.18 同一人物で治療 前のあのである。

生理範囲よりはみでた值のバラツきは、病理学的身 体の不調を示すすのでなく、患者の訴える症状が多い ととを示す。

Fig. 19

治療を行うべき点は、刺激を受けると体内に均衡を あたらすので、慢性的な症状の治療に欠かせない。中 谷博士は、多くの患者を治療してきた経験に基づき、 Fig. 20、Fig. 21 にみられるように上肢、下肢上のこ れらの点を治療すべき点として勧めてきた。しかしな がら電導性を高めるための high point（興偪点）や 電導性を低くするための low point（抑制点）の選択 は、絶対に必要だというわけではない。前述のホメオ スターシスの為である。将来の研究として、良導絡力 ルテの修整が考えられよう。ただし、良導絡カルテが 臨床上意義を認められてきた治療の研究の基礎として 有益であることは事実である。

Fig. 20

Fig. 21
一般基本点（基本調整点）

これらの一般基本点（最もよく使われるその基本点 2 型) は、通常、一般調節治療と組合わせて用いるこ とを勧める。

Head \& neck point 頭、首の点

これも同上、ほとんどの慢性疾患の為の局所一般治 療の勃果を高める為に用いるへきである。

ノイロメーターの説明 (良導絡療法に用いられる器 具)

ノイロメーター上の目もりは、マイクロアンペア刻 みになっている。メーターの下には 3 つのダイアルか ある。中央のダイアルで電圧（6、12、21Volt）を調 節し、左側のダイアルで電流を調節する。ダイアルの 下には、にぎり導子と 2 つの探知電極がある。

Fig. 22

最す効果的な反応良導点は、ノイロメーターの目盛 りから見つけ出すととができる。患者は片手にプラス の電極を持つ。マイナスの䉓極は反応良導点を探知す る為のものである。電圧は 12 Volt (直流) で、湿式

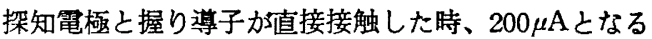
ように、前もって䉓流を設定する。

Fig. 23

これらは S T-36（足三里）の反応良導点である。 ノイロメーターの最大值に注目するとと。実際の場 合、ほとんどの反応良尊点は、従来針のツボとされて きた点か、またはその近くにある。

反応良導点を結んだ線は、良導絡（電気のよく通る 点を結んだ線、経絡）と呼ばれる。針のツボと経絡の 全てが、いつあ電気伝導性が高いというわけではな い。反応良導点は患者の病理、生理学的徵候の現われ なのである。このスライドでは、反応良導点を結ぶ線 が、従来の堅臟の経絡とほほ一致しているととを示す が、これは中谷博士が、腎炎の患者の電気の良く通る 点を探しているときに、はじめて発見された。この発 見は、良導絡理論とその実践発展へつながっていく。

皮フの抵抗をスポット毎に、自動的に测定する近代 的な方法が開発された。我々は、コンピューターを導 入し、オンラインシステム化した。 $1 \mathrm{~cm}^{2}$ の湿式電極 が、皮フ上に均等に取りつけられ、次々にスイッチを 入れて、自動ノイロ計算機でアンペアを測定する。 0.5 秒どとの測定值がコンピューターにインプットさ れる。

次にコンピューターは式によって、B点の導電率 と、あるスポットの両側（AとC）の導電率との差の 割合を計算する。この值は、身体の部分別、たとえ ば、顔面、背中、前腕、肩、足について計算する。こ の差が50\%以上であれば、そこが良導点である。 
両側の䉓極の電流量 $(\mu \mathrm{A})$ を上記の数式により比 较する。

$\mathrm{M}$ （\%）：良導点の範围……50\%以上

$\mathrm{M}=50 \%$ 以上の時、 $\mathrm{B}$ 点は良導点

多くの良導点は、コンピューターのオンラインシス テムを用いて、慢性腎不全の患者の左足の内側から発 見されたものである。測定過程に人問的要素の入る余 地が全くないので、この結果は客観的であると言えよ う。とれらの点は、その両側の点と比へ、計算値Mが 50\%以上であったあのだが、従来の針のツボである。 （チキ） $\mathrm{F}_{18} 8$ (S P 8)、（インポー) $\mathrm{F}_{210}$ (L V 9)、(インリョーセン) $\mathrm{F}_{19}$ (S P 9)、（チクヒ ン) F 310 (K I 9)、(インコク) K I 10 (F F11) な ど一致している。との比率は、ある点とその付近の導 電率の比較の為の数式（前述）によって算出されたも のである。従来の経絡によれば、これらの反応良導点 を結ぶ線は、 $\mathrm{F}_{1}$ (脾経)、 $\mathrm{F}_{2}$ (肝経)、 $\mathrm{F}_{3}$ (堅経) 等とほほ一致する。

新品のハリと、中谷博士が患者一人の治療に使用し たハリの拡大で両者を比較したすのである。12V．

DC、150 $\mu \mathrm{A}$ で1500回ジャクタクした。ハリの表面は すり減って、ハリの表面の中心近くには、ハリと皮フ の摩擦によってできたてまかな細い線（スリきずの様 な）ができている。

新品のハリと中谷博士が 7 人の患者の治療使用し た釬との比較で、この針は数多くの刺入に使われたも のである。針先が丸くなっているが、てれは電流の為 ではなく、組織を貫入するてとによる機械的摩耗のせ いである。

\section{6. 日本における良栾絡治㾌の実践の現状調查}

琴在日本では、良導絡自律神経学会に所属する医師 は935名、銊尒師は300名である。しかし、日本の医師 で良導絡治療を行っている医師は 4 万名以上に及ふ。。 日本における良導絡治療の実態に関するデーターを収 集する為、学会の会員にアンケートを送った。 アンケートの項目の中には、良導絡治灙が最も勃果 のある病気、良導絡治療の副作用及び合併症、治療効 果をあげるのに必要な期間などが含まれている。

良導絡治療の適応疾患の疼通を伴う疾患について示 す。最低は 5 名以上の医師が返答した疾病が順に並ん でいる。背中下部の痛み、神経痛、首や肩の痛みの治 療に良導絡は最も効果的だった。

良導絡適応疾患之症候を示す。首、肩、腕に関する 症状加最も多く、以下順代気管支喘息、自律神経系の 疾患之続いている。良導絡治療による副作用と併発症
に関するあのである。 副作用（報告数合計238）

1. 急性脳貧血

2. 疾 労

3. 局部的な痛み

4. ショック

5. 悪 化

6. 血腫

7. 気胸

8. 折 針

9. 眼 気

10. 発 熱

11. メマイ

12. 吐気、嘔吐 その他

以上、急性贫血、疲労、局部的な病気、ショックな ぞ、一般的な副作用は、一時的なあのである。

$\left.\begin{array}{ll}\text { 気胸 } 16 \text { 例（報告例10） } 6 \% \text { （4\%） } \\ \text { 折針 } 10 \text { 例（報告例 8） } 4 \% \text { (3\%) }\end{array}\right\} 230$ 人中

これらは重い合併症の 2 例である。しかしてれらは 実際は、不注意によるミスから起ったものである。従 って、患者の治療にあたっては、常に紐心の注意を払 うことを要する。次に治療の効果が出るのに必要な期 間については、多くの急性疾患の場合は、治療は 1 日 以内で改善する。

1972年中谷博士により、慢性疼痛に対し良導絡治療 のみを施した患者についての要約である。ての表中の 全症例の結果は、追跡調查により確認された。79例 中、76例（96\%）について、回復及び症状の好転が見 られた。

\section{良導絡治療の要約}

良導絡治療の主な特徵についてまとめると次の通り である。

第 1.そのテクニックは、非特異的刺激治療法の一種 として、理解がしやすい。

第 2. 従来の治療についての訓練のみを受けた医師で も、容易に臨床で実践を行なうことができる。

第 3. 判断の基準が電気 (ノイロメーター) を使って 得られるので、治療すべき点がみつかる。

第 4. 安全で信頼しうる方法である。

第 5. (最後に)良導絡治療法は、八リ治療の科学的根 拠の理解へのステップであり、その勃果に疑問 を抱いている医師を納得させるのに役立つ。

本文は昭和56年10月第71回国際針炎学会に講演した ものである。 